\title{
PENINGKATAN AKSES JALAN UNTUK MENUNJANG DISTRIBUSI HASIL PRODUKSI KOTA TERPADU MANDIRI (KTM) AIR TERANG KABUPATEN BUOL
}

\author{
Windra Priatna Humang ${ }^{1}$, Amrin ${ }^{2}$ \\ ${ }^{1}$ Dosen Program Studi Teknik Sipil Universitas Andi Djemma Palopo \\ ${ }^{2}$ Pegawai Dinas Pekerjaan Umum Kabupaten Buol Sulawesi Tengah \\ 1indrahumang@gmail.com
}

\begin{abstract}
Abstrak
Penelitian ini bertujuan (1) menjelaskan potensi kawasan Kota Terpadu Mandiri Air Terang terhadap permintaan pergerakan transportasi, (2) merumuskan strategi pengembangan jaringan jalan untuk menunjang distribusi hasil produksi pada kawasan Kota Terpadu Mandiri (KTM) Air Terang. Penelitian yang digunakan adalah studi kasusdengan pendekatan metodepenelitian deskriptif kualitatif dan kuantitatif, untuk melihat secara umum wilayah studi dan bertujuan menggambarkan secara sistematis, cermat dan akurat dalam menganalisis potensi sumber daya alam wilayah, mengidentifikasi kondisi jaringan jalan serta penyediaan prasarana jalan sebagai faktor penting yang akan berpengaruh pada tingkat pencapaian fungsi Kota Terpadu Mandiri (KTM) Air Terang Kabupaten Buol. Data dianalisis dengan menggunakan metode analisis LQ, Skalogram dan SWOT. Hasil analisa dan pembahasan menunjukkan bahwa prasarana transportasi di Kabupaten Buol belum terpadu, efektif dan efisien dalam menunjang pengembangan wilayah transmigrasi yang diprogramkan oleh kementeriantransmigrasi dan pedesaan melalui program pengembangan Kota Terpadu Mandiri. Jaringan jalan arteri dan kolektor sebagai prasarana transportasi yang menghubungkan antar wilayah kecamatan belum berfungsi dengan baik dalam mendistribusi hasil produksi kepusat distribusi dimana kondisi jalan sebagian besar mengalami rusak berat sehingga perlu penanganan yang serius oleh pemerintah daerah Kabupaten Buol. Strategi pengembangan jaringan jalan yang perlu diprioritaskan adalah pembangunan/pemeliharaan jaringan jalan menuju kawasan-kawasan potensial untuk menunjang pertumbuhan dan pengembangan wilayah, serta peningkatan sarana transportasi dalam mendukung mobilitas penduduk sehingga potensi sumberdaya alam dapat dimafaatkan guna meningkatkan kesejahteraan masyarakat transmigrasi yang ada di Kabupaten Buol.
\end{abstract}

Kata kunci : CTAM, Aspal, Prosedur Marshall.

\section{PENDAHULUAN}

Transportasi mempunyai peranan yang sangat penting dalam pengembangan suatu wilayah, yaitu memudahkan interaksi antar wilayah. Kemudahan berinteraksi antar wilayah akan membawa manfaat ekonomi dan sosial. Jaringan jalan/transportasi yang baik akan merangsang bangkitnya pergerakan penduduk untuk melakukan kegiatan sosial ekonomi. Hal tersebut menunjukkan bahwa pembangunan jaringan jalan/transportasi mempunyai hubungan timbal balik dengan perekonomian suatu daerah untuk menunjang pertumbuhan dan pengembangan kawasan perkotaan dan pedesaan. Transportasi yang diartikan sebagai kegiatan yang melakukan pengangkutan atau pemindahan muatan (yang terdiri dari barang dan manusia) dari suatu tempat ketempat lain, dari tempat asal (origin) ke tempat tujuan (destination). Perjalanan dari tempat asal menuju tempat tujuan di sebut Origin Destination Travel (OD Travel).

Berdasarkan Master Plan Kota Terpadu Mandiri Kabupaten Buol (2006) bahwa letak Kota Terpadu Mandiri (KTM) Air Terang merupakan kawasan transmigrasi yang meliputi empat wilayah kecamatan yaitu Kecamatan Bokat, Kecamatan Bukal, Kecamatan Momunu dan Kecamatan Tiloan. Kota Terpadu Mandiri (KTM) Air Terang adalah wilayah transmigrasi yang pengembangannya dirancang menjadi pusat pertumbuhan melalui pengelolaan sumber daya alam 
berkelanjutan yang mempunyai fungsi sebagai pusat kegiatan pertanian berupa pengolahan barang pertanian jadi dan setengah jadi serta kegiatan agribisnis, pusat pelayanan agroindustri khusus (special agroindustry services) serta pendidikan, pelatihan di sektor Pertanian, Industri dan Jasa.

Potensi pengembangan sumber daya alam di wilayah KTM Air Terang di Kabupaten Buol sangat besar, terutama pada beberapa jenis tanaman pertanian maupun tanaman perkebunan. Sejalan dengan pengembangan wilayah kawasan KTM Air Terang di Kabupaten Buol, maka dipandang perlu untuk memaksimalkan pemanfaatan jaringan jalan yang tersedia agar dapat digunakan secara maksimal dalam mendukung pengembangan wilayah KTM Air Terang. Pengembangan jaringan jalan di Kabupaten Buol khususnya dikawasan Kota Terpadu Mandiri (KTM) Air Terang diharapkan mampu meningkatkan aksebilitas pergerakan yang berorientasi pada distribusi hasil-hasil pertanian yang ada serta bertujuan untuk meningkatkan pendapatanmasyarakat pada sektor pertanian dan perkebunan.

Dalam rangka mendukung program penegembangan wilayah transmigrasi melalui sistim pengembangan wilayah Kota Terpadu Mandiri (KTM) yang dicanangkan oleh Departemen Transmigrasi yang diharapkan mampu memacu pertumbuhan ekonomi wilayah maka dibutuhkan jaringan jalan yang memadai olehnya itu diperlukan langkah guna memaksimalkan kinerja jaringan jalan yang ada dalam mendukung pergerakan distribusi barang dan jasa yang lebih efektif, efisien dan terpadu. Apabila dilihat dalam konstelasi pembangunan dan pengembangan wilayah Sulawesi Tengah, maka Kabupaten Buol diklasifikasikan sebagai kota hirarki/orde III dengan fungsi pelayanan pusat kegiatan wilayah untuk tingkat kabupaten. Dengan kedudukan yang demikian ini secara langsung kecamatankecamatan yang termasuk wilayak kota terpadu mandiri (KTM) menjadi kota hirarki dibawahnya dan diharapkan memberikan pelayanan yang berorientasi ke Kota Buol. Maka untuk tujuan penelitian ini adalah menjelaskanpotensi kawasan KTM Air Terang terhadap permintaan pergerakan transportasi serta merumuskan strategi pengembangan jaringan jalan untuk menunjang distribusi hasil produksi ke Kota Buol.

\section{TINJAUAN PUSTAKA}

Dalam Sistranas 2005 mangatakan bahwa sistem transportasi terdapat dua aspek yang sangat penting, yakni aspek sarana dan prasarana. Kedua aspek ini sering disebut sebagai bagian yang mempunyai peranan dalam menunjang kesejahteraan dan kebutuhan masyarakat dalam beraktifitas. Transportasi diartikan sebagai pemindahan manusia dan barang dari tempat asal ke tempat tujuan serta fasilitas yang digunakan untuk tujuan tersebut. Sistem transportasi berkaitan erat dengan sistem aktifitas dan sistem lalu lintas yang ada, karena transportasi merupakan permintaan turunan yaitu permintaan yang timbul akibat permintaan yang lain. (Jinca, 2002;1-7). Morlok, E. K., (1991) dalam Miro, (1997:5) membagi komponen utama transportasi sebagai berikut:
a) Orang dan barang (yang diangkut)
b) Kendaraan (alat angkut)
c) Jalan (tempat alat angkut bergerak)
d) Terminal (tempat menurunkan dan menaikkan barang maupun penumpang).
e) Sistem pengoperasian (yang mengatur ke empat komponen tersebut di atas). 
Secara umum komponen sistem trasportasi dapat diuraikan sebagai berikut (Kodotie; 2005:353) : (1) Lintasan atau jalur sebagai tempat benda tadi bergerak; (2) Terminal dan pelabuhan merupakan simpul keluar masuk kendaraan dari maupun ke sistem dan sebagai tempat pergantian moda transportasi; (3) Kendaraan yang memberikan sesuatu mobilitas terhadap benda yang diangkut untuk suatu jalur gerak tertentu dan dapat digerakkan di jalur tersebut; (4) Rencana operasi atau prosedur pengaturan yang dapat menjamin kegiatan transportasi (lalu lintas orang dan barang) bergerak secara aman, lancar dan tertib. Undang-undang RI No.38 tahun 2004 tentang jalan pada pasal 7 menjelaskan bahwa sistem jaringan jalan terdiri atas:

a) Sistem jaringan jalan primer merupakan sistem jaringan jalan dengan peranan pelayanan distribusi barang dan jasa untuk pengembangan wilayah ditingkat nasional, dengan menghubungkan semua simpul jasa distribusi yang berwujud pusat-pusat kegiatan.

b) Sistem jaringan jalan sekunder merupakan sistem jaringan jalan dengan peranan pelayanan distribusi barang dan jasa untuk masyarakat didalam kawasan perkotaan.

Pengembangan wilayah menurut Adisasmita, R., (2005:48) adalah sebagai upaya pembangunan pada suatu wilayah atau beberapa daerah untuk mencapai kesejahteraan masyarakat dengan memanfaatkan sumber-sumber daya (alam, manusia, kelembagaan, teknologi dan prasarana) secara efektif, optimal dan berkelanjutan dengan cara menggerakkan kegiatan-kegiatan produktif (sektor primer, sekunder dan tersier), penyediaan fasilitas pelayanan (ekonomi dan sosial), penyediaan prasarana dan sarana serta lingkungan. Keseluruhan usaha yang mengarah pada perbaikan dalam tingkat kesejahteraan hidup masyarakat pada umumnya dapat dipandang sebagai penyebab berlangsungnya proses berkembangnya wilayah.

\section{METODE PENELITIAN}

Jenis penelitian yang digunakan adalah studi kasusdengan pendekatan metodepenelitian deskriptif dengan analisis kualitatif dan kuantitatif, untuk melihat secara umum wilayah studi dan bertujuan menggambarkan secara sistematis, cermat dan akurat dalam menganalisis potensi sumber daya alam wilayah, mengidentifikasi kondisi jaringan jalan serta penyediaan prasarana jalan sebagai faktor penting yang akan berpengaruh pada tingkat pencapaian fungsi Kota Terpadu Mandiri Air Terang Kabupaten Buol. Penelitian yang dilakukan adalah penelitian yang memerlukan berbagai jenis data yakni dengan metode pengumpulan data yang bersifat kombinasi antara metode observasi, interview atau wawancara,hal ini dilakukan dalam rangka memaksimalkan tingkat kebenaran data dan informasi.

\section{PEMBAHASAN}

Potensi Sumber Daya Alam

Luas Kawasan KTM sekitar $158.000 \mathrm{Ha}$ yang terdiri dari $17.775 \mathrm{Ha}$ merupakan lahan dataran, 35.886 Ha lahan landai, 44.729 Ha lahan bergelombang dan 59.629 Ha lahan curam/gunung. Lahan tersebut merupakan lahan yang subur dengan curah hujan cukup (6 bulan basah) dan sesuai untuk dikembangkan tanaman perkebunan maupun tanaman pangan seperti padi, jagung, palawija, jeruk, coklat dan kelapa sawit. Untuk luas panen dan hasil produksi tanaman pangan yang berada diwilayah KTM tahun 2010 dapat dilihat pada tabel : 
Tabel 1. Luas panen dan produksi padi sawahdan ladang

\begin{tabular}{|c|c|c|c|c|c|c|c|}
\hline \multirow[b]{2}{*}{ No } & \multirow[b]{2}{*}{ Kecamatan } & \multicolumn{2}{|c|}{ Padi sawah } & \multicolumn{2}{|c|}{ Padi Ladang } & \multicolumn{2}{|c|}{ Jumlah } \\
\hline & & $\begin{array}{c}\text { Luas } \\
\text { (ha) }\end{array}$ & $\begin{array}{c}\text { Prod. } \\
\text { (ton) }\end{array}$ & Luas (ha) & $\begin{array}{c}\text { Prod. } \\
\text { (ton) }\end{array}$ & Luas (ha) & $\begin{array}{l}\text { Prod. } \\
\text { (ton) }\end{array}$ \\
\hline 1 & Momunu & 714 & 2.142 & 7 & 21 & 721 & 2.216 \\
\hline 2 & Tiloan & 1.953 & 14.647 & - & - & 1.953 & 14.647 \\
\hline 3 & Bukal & 737 & 2.800 & 17 & 64 & 754 & 2.864 \\
\hline 4 & Bokat & 1.030 & 3.090 & 14 & 42 & 1.044 & 3.132 \\
\hline & Jumlah & 4.434 & 22.679 & 38 & 127 & 4.472 & 22.806 \\
\hline
\end{tabular}

Sumber: Dinas Pertanian Kab. Buol tahun 2010

Tabel 2. Luas panen dan produksi palawija

\begin{tabular}{|c|c|c|c|c|c|c|c|c|c|c|c|c|c|}
\hline \multirow{2}{*}{ No } & \multirow{2}{*}{ Kecamatan } & \multicolumn{2}{|c|}{ Jagung } & \multicolumn{2}{|c|}{ Kedele } & \multicolumn{2}{|c|}{ Kacang Hijau } & \multicolumn{2}{|c|}{$\begin{array}{c}\text { Kacang } \\
\text { Tanah }\end{array}$} & \multicolumn{2}{|c|}{ Ubi Kayu } & \multicolumn{2}{|c|}{ Ubi Jalar } \\
\hline & & $\begin{array}{c}\text { Luas } \\
\text { (ha) }\end{array}$ & $\begin{array}{l}\text { Prod. } \\
\text { (ton) }\end{array}$ & $\begin{array}{c}\text { Luas } \\
\text { (ha) }\end{array}$ & $\begin{array}{l}\text { Prod. } \\
\text { (ton) }\end{array}$ & $\begin{array}{c}\text { Luas } \\
\text { (ha) }\end{array}$ & $\begin{array}{l}\text { Prod. } \\
\text { (ton) }\end{array}$ & $\begin{array}{c}\text { Luas } \\
\text { (ha) }\end{array}$ & $\begin{array}{l}\text { Prod. } \\
\text { (ton) }\end{array}$ & $\begin{array}{l}\text { Luas } \\
\text { (ha) }\end{array}$ & $\begin{array}{l}\text { Prod. } \\
\text { (ton) }\end{array}$ & $\begin{array}{l}\text { Luas } \\
\text { (ha) }\end{array}$ & $\begin{array}{l}\text { Prod. } \\
\text { (ton) }\end{array}$ \\
\hline 1 & Momunu & 34 & 136 & 13 & 52 & 4 & 6 & 46 & 184 & 15 & 90 & 13 & 78 \\
\hline 2 & Tiloan & 252 & 1.008 & 240 & 960 & 41 & 61 & 87 & 348 & 25 & 150 & 24 & 144 \\
\hline 3 & Bukal & 295 & 1.445 & 14 & 68 & 3 & 4 & 68 & 333 & 3 & 18 & 22 & 132 \\
\hline 4 & Bokat & 48 & 187 & 59 & 187 & 12 & 18 & 12 & 46 & - & - & - & - \\
\hline & Jumlah & 629 & 2.776 & 326 & 1.267 & 60 & 89 & 213 & 911 & 43 & 258 & 59 & 354 \\
\hline
\end{tabular}

Sumber: Dinas Pertanian Kab. Buol tahun 2010

Tabel 3. Luas panen dan produksi tanaman perkebunan rakyat (tanaman tahunan)

\begin{tabular}{|c|c|c|c|c|c|c|c|c|c|c|c|c|c|}
\hline \multirow[b]{2}{*}{ No } & \multirow{2}{*}{ Kecamatan } & \multicolumn{2}{|c|}{ Kakao } & \multicolumn{2}{|c|}{$\begin{array}{l}\text { Kelapa } \\
\text { Dalam }\end{array}$} & \multicolumn{2}{|c|}{ Cengkeh } & \multicolumn{2}{|c|}{$\begin{array}{c}\text { Kopi } \\
\text { Robusta }\end{array}$} & \multicolumn{2}{|c|}{ Nilam } & \multicolumn{2}{|c|}{ Pala } \\
\hline & & $\begin{array}{l}\text { Luas } \\
\text { (ha) }\end{array}$ & $\begin{array}{l}\text { Prod. } \\
\text { (ton) }\end{array}$ & $\begin{array}{l}\text { Luas } \\
\text { (ha) }\end{array}$ & $\begin{array}{l}\text { Prod. } \\
\text { (ton) }\end{array}$ & $\begin{array}{l}\text { Luas } \\
\text { (ha) }\end{array}$ & $\begin{array}{l}\text { Prod. } \\
\text { (ton) }\end{array}$ & $\begin{array}{l}\text { Luas } \\
\text { (ha) }\end{array}$ & $\begin{array}{l}\text { Prod. } \\
\text { (ton) }\end{array}$ & $\begin{array}{l}\text { Luas } \\
\text { (ha) }\end{array}$ & $\begin{array}{l}\text { Prod. } \\
\text { (kg) }\end{array}$ & $\begin{array}{l}\text { Luas } \\
\text { (ha) }\end{array}$ & $\begin{array}{l}\text { Prod. } \\
\text { (ton) }\end{array}$ \\
\hline 1 & Momunu & 80 & 680 & 100 & 1.204 & 75 & 25,9 & 75 & 26,9 & 40 & 189,7 & 35 & 0,18 \\
\hline 2 & Tiloan & 500 & 1.930 & 25 & 390 & 300 & 7 & 75 & 35,9 & 50 & 155,4 & 25 & 0,18 \\
\hline 3 & Bukal & 350 & 2.518 & 150 & 770 & 50 & 8 & 30 & 9,7 & 150 & $1.169,9$ & 50 & 0,42 \\
\hline 4 & Bokat & 200 & 966 & 112 & 2.419 & 50 & 10,5 & 50 & 50,9 & 100 & 200 & 50 & - \\
\hline & Jumlah & 1.130 & 6.094 & 387 & 4.783 & 475 & 51,4 & 230 & 123,4 & 340 & 1.715 & 160 & 0,78 \\
\hline
\end{tabular}

Sumber: Dinas Perkebunan Kab. Buol tahun 2010

Tabel 4. Luas panen dan produksi tanaman perkebunan rakyat (tanaman tahunan)

\begin{tabular}{ccccccccccccc}
\hline \multirow{2}{*}{ No } & Kecamatan & \multicolumn{2}{c}{ Jambu Mente } & \multicolumn{2}{c}{ Lada } & \multicolumn{2}{c}{ Panili } & \multicolumn{2}{c}{ Kapuk } & \multicolumn{2}{c}{ Sagu } \\
& & (ha) & Prod. & \multicolumn{2}{c}{$\begin{array}{c}\text { Luas } \\
\text { (ton) }\end{array}$} & $\begin{array}{c}\text { Prod. } \\
\text { (ton) }\end{array}$ & $\begin{array}{l}\text { Luas } \\
\text { (ha) }\end{array}$ & $\begin{array}{c}\text { Prod. } \\
\text { (ton) }\end{array}$ & $\begin{array}{l}\text { Luas } \\
\text { (ha) }\end{array}$ & $\begin{array}{c}\text { Prod. } \\
\text { (ton) }\end{array}$ & $\begin{array}{l}\text { Luas } \\
\text { (ha) }\end{array}$ & $\begin{array}{c}\text { Prod. } \\
\text { (ton) }\end{array}$ \\
\hline 1 & Momunu & 25 & - & 35 & 0,22 & 15 & - & 15 & 0,68 & 10 & 374 \\
2 & Tiloan & - & - & 50 & 0,10 & 400 & 0,18 & 2 & 0,62 & - & - \\
3 & Bukal & - & - & 10 & 0,3 & 10 & 0,06 & 10 & 0,72 & - & - \\
4 & Bokat & 45 & 0,04 & 40 & 0,10 & 20 & - & 25 & 2,4 & 50 & 70 \\
\hline & Jumlah & 70 & 0,04 & 135 & 0,72 & 455 & 0,24 & 52 & 4,42 & 60 & 444 \\
\hline
\end{tabular}

Sumber: Dinas Perkebunan Kab. Buol tahun 2010

Potensi sumber daya hutan berupa ketersediaan kawasan hutan negara yang terdapat diwilayah Kabupaten Buol adalah seluas 258.228 ha $(61,95 \%)$ dari luas wilayah daratan Kabupaten Buol dari luas tersebut 73.404 ha adalah kawasan lindung dan seluas 184.824 ha merupakan kawasan budidaya hutan. Potensi hasil hutan berupa kayu dan bukan kayu (rotan, getah, bambu, biji dll) cukup tersedia dikawasan hutan Kabupaten Buol yang diantaranya : 1) hasil hutan yang bernilai komersial antara lain : Palapi (Heritiera sp), Nyatoh (Palaqium sp), Cempaka (Elmerillia sp), Agatis (Agathis sp), Maranti (Shorea sp), Bintangur (calophylum 
inophyllum), Matoa (Pometia pinnata), Dao (Dracontamelon dao), Binuang (Octomeles sumatrana), mangga hutan (Mangifera foetida); 2) hasil hutan bukan kayu antara lain : Rotan (Calamus sp), Bambu (Bambusa sp) dll.; 3) hasil multi guna antara lain : Agatis (kayu, getah damar), aren (nira, gula aren, ijuk, tepung aren), Durian (kayu, buah) dll.

\section{Potensi Sosial Ekonomi}

Jumlah penduduk di Kawasan KTM ini sejumlah 45.553 jiwa atau sekitar 38,2 \% dari jumlah penduduk Kab. Buol dan didukung 33,4 \% warga eks transmigran atau 15 lokasi permukiman transmigrasi. Mata pencaharian utama dikawasan ini adalah pada sektor kegiatan pertanian, perkebunan dan peternakan atau sekitar 84,5\% dan sisanya pada sektor perdagangan, jasa , industri, kontruksi dan pemerintahan. Tabel jumlah penduduk dapat dilihat :

Tabel 5. Luas Wilayah, Jumlah Penduduk, Kepadatan dan Rasio Sekswilayah KTM.

\begin{tabular}{ccccccc}
\hline No & Kecamatan & $\begin{array}{c}\text { Luas Areal } \\
\left(\mathrm{Km}^{2}\right)\end{array}$ & $\begin{array}{c}\text { Jumlah } \\
\text { Penduduk }\end{array}$ & $\begin{array}{c}\text { Kepadatan } \\
(\mathrm{Km})\end{array}$ & Rasio Sex & $\begin{array}{c}\text { Laju Pertumbuhan } \\
\text { Penduduk }(\%)\end{array}$ \\
\hline 020 & Momunu & 400,40 & 13.377 & 33,4 & 103,5 & 1,58 \\
021 & Tiloan & $1.437,7$ & 7.693 & 5,4 & 108,7 & 1,58 \\
030 & Bokat & 196,10 & 12.219 & 62,3 & 102,1 & 1,60 \\
031 & Bukal & 355,52 & 12.264 & 34,5 & 106,3 & 1,60 \\
\hline & Jumlah & $\mathbf{2 3 8 9 , 7 2}$ & $\mathbf{4 5 . 5 5 3}$ & $\mathbf{3 3 , 9}$ & $\mathbf{1 0 5 , 1 5}$ & $\mathbf{1 , 5 9}$ \\
\hline
\end{tabular}

Sumber: Kabupaten Buol dalam Angka Tahun 2010

Kondisi perekonomian suatu daerah biasanya ditunjukkan oleh beberapa indikator ekonomi makro. Salah satu indikator utama perekonomian adalah PDRB dimana beberapa variabel yang terkait langsung dengan PDRB diantaranya struktur perekonomian, laju pertumbuhan ekonomi, serta PDRB per kapita. Untuk tahun 2009 struktur perekonomian khususnya di Kabupaten Buol secara menyeluruh didominasi oleh sektor pertanian yaitu sebesar 55,48 \%, sedangkan untuk sektor lainnya terdiri dari : sektor penggalian $0,87 \%$, industri pengolahan $7,66 \%$, listrik dan air bersih $0,68 \%$, bangunan $5,33 \%$, perdagangan hotel dan restoran $10,49 \%$, angkutan dan komunikasi 3,55\%, keuangan persewaan dan jasa perusahaan 3,30\%, serta jasa-jasa $9,24 \%$.

\section{Simpul-simpul Produksi}

Untuk mengetahui simpul-simpul produksi berdasarkan wilayah maka dapat dilihat dari keunggulan tiap wilayah kecamatan menurut jenis Jenis tanaman pangan dan pala wija serta perkebunan rakyat tersebut, maka digunakan rumus LQ. Dari hasil perhitungan tersebut di peroleh gambaran beberapa wilayah kecamatan yang merupakan daerah simpul produksi dari jenis tanaman yang dikembangkan sebagaimana pada tabel 5 dan 6 di bawah ini :

Tabel 6. Hasil Perhitungan LQ Produksi Padi dan Palawija

\begin{tabular}{cccccccccc}
\hline No & Kecamatan & $\begin{array}{c}\text { Padi } \\
\text { Sawah } \\
\text { (Ton) }\end{array}$ & $\begin{array}{c}\text { Padi } \\
\text { Ladang } \\
\text { (Ton) }\end{array}$ & $\begin{array}{c}\text { Jagung } \\
\text { (Ton) }\end{array}$ & $\begin{array}{c}\text { Kc. } \\
\text { Kedelai } \\
\text { (Ton) }\end{array}$ & $\begin{array}{c}\text { Kc } \\
\text { Hijau } \\
\text { (Ton) }\end{array}$ & $\begin{array}{c}\text { Kc } \\
\text { Tanah } \\
\text { (Ton) }\end{array}$ & $\begin{array}{c}\text { Ubi } \\
\text { Kayu } \\
\text { (Ton) }\end{array}$ & $\begin{array}{c}\text { Ubi } \\
\text { Jalar } \\
\text { (Ton) }\end{array}$ \\
\hline 1 & Momunu & 0,99 & 1,74 & 0,51 & 0,43 & 0,71 & 2,12 & 3,66 & 2,31 \\
2 & Tiloan & 1,06 & 0,00 & 0,60 & 1,25 & 1,13 & 0,63 & 0,96 & 0,67 \\
3 & Bukal & 0,72 & 2,95 & 3,05 & 0,31 & 0,26 & 2,14 & 0,41 & 2,18 \\
4 & Bokat & 1,09 & 2,64 & 0,54 & 1,18 & 1,61 & 0,40 & 0,00 & 0,00 \\
\hline
\end{tabular}

Sumber : Hasil Analisis 
Tabel 7. Hasil Perhitungan LQ Produksi Tanaman Perkebunan Rakyat.

\begin{tabular}{|c|c|c|c|c|c|c|c|c|c|c|c|c|}
\hline No & Kecamatan & $\begin{array}{l}\text { Kakao } \\
\text { (Ton) }\end{array}$ & $\begin{array}{c}\text { Kelap } \\
\text { a } \\
\text { (Ton) }\end{array}$ & $\begin{array}{l}\text { Cengkeh } \\
\text { (Ton) }\end{array}$ & $\begin{array}{c}\text { Kopi } \\
\text { Robusta } \\
\text { (Ton) }\end{array}$ & $\begin{array}{l}\text { Nilam } \\
\text { (Ton) }\end{array}$ & $\begin{array}{l}\text { Pala } \\
\text { (Ton) }\end{array}$ & $\begin{array}{l}\text { Jambu } \\
\text { Mente } \\
\text { (Ton) }\end{array}$ & $\begin{array}{l}\text { Lada } \\
\text { (Ton) }\end{array}$ & $\begin{array}{l}\text { Panili } \\
\text { (Ton) }\end{array}$ & $\begin{array}{l}\text { Kapuk } \\
\text { (Ton) }\end{array}$ & $\begin{array}{l}\text { Sagu } \\
\text { (Ton) }\end{array}$ \\
\hline 1 & Momunu & 1,71 & 1,33 & 2,66 & 1,15 & 0,58 & 1,22 & 0,00 & 1,61 & 0,00 & 0,81 & 4,45 \\
\hline 2 & Tiloan & 1,66 & 0,43 & 0,71 & 1,53 & 0,48 & 1,21 & 0,00 & 0,73 & 3,93 & 0,74 & 0,00 \\
\hline 3 & Bukal & 1,22 & 0,48 & 0,46 & 0,23 & 2,01 & 1,59 & 0,00 & 1,23 & 8,86 & 0,48 & 0,00 \\
\hline 4 & Bokat & 0,56 & 1,80 & 0,73 & 1,47 & 0,41 & 0,00 & 3,55 & 0,49 & 0,00 & 1,93 & 0,56 \\
\hline
\end{tabular}

Sumber: Hasil Analisis

Dari tabel diatas menunjukkan simpul-simpul produksi untuk setiap kecamatan berbeda berdasarkan nilai LQ $>1$ dimana untuk produk padi dan palawija untuk masing-masing kecamatan menyadi sentra produksi unggulan untuk masingmasing jenis tanaman, demikian pula halnya dengan tanaman perkebunan rakyat. Dari hasil analisis dapat dilihat bahwa simpul produksi untuk semua jenis tanaman terbesar dihasilkan oleh kecamatan momunu dan tiloan. Kesemua hasil produksi tersebut dipasarkan dikota Buol dengan melalui transportasi darat namun hal ini belum ditunjang dengan sarana dan prasarana transportasi yang memadai dimana sarana yang digunakan oleh masyarakat didaerah ini meliputi kendaraan roda empat dan roda dua. Untuk kendaraan roda empat yang beroperasi sebagai angkutan umum jumlahnya relatif kecil yang belum dapat memenuhi kebutuhan masyarakat dalam mengangkut barang maupun jasa, sementara kendaraan roda dua jumlahnya lebih besar karna dijadikan kendaraan alternatif, hal ini diakibatkan pula dengan kondisi prasarana jalan yang sebahagian besar mengalami rusak berat. Keterbatasan sarana dan prasarana ini berpengaruh pada distribusi hasil-hasil produksi yang akan diangkut sampai kepasar yang ada di kota Buol dan kota lain disekitarnya.

Prasarana Transportasi

a) Prasarana jaringan jalan

Luas wilayah Kabuapten Buol adalah 4.043,57 Km dengan ketersediaan infrastruktur berupa fasilitas jalan dimana untuk jalan berdasarkan statusnya yakni jalan nasional sepanjang $194 \mathrm{Km}$, jalan provinsi sepanjang $43 \mathrm{Km}$ dan jalan kabupaten sepanjang 780,40 Km dan kondisi dari jalan tersebut dapat dilihat pada tabel berikut :

Tabel 8. Panjang Jalan Menurut Status dan Keadaan Jalan

\begin{tabular}{|c|c|c|c|c|c|c|c|c|c|}
\hline \multirow[b]{2}{*}{ No } & \multirow[b]{2}{*}{ Status Jalan } & \multirow[b]{2}{*}{$\begin{array}{c}\text { Total } \\
\text { Panjang } \\
(\mathrm{Km})\end{array}$} & \multicolumn{3}{|c|}{ Jenis Perkerasan } & \multicolumn{4}{|c|}{ Kondisi Jalan } \\
\hline & & & $\begin{array}{l}\text { Aspal } \\
(\mathrm{Km})\end{array}$ & $\begin{array}{c}\text { Kerikil } \\
(\mathrm{Km})\end{array}$ & $\begin{array}{l}\text { Tanah } \\
(\mathrm{Km})\end{array}$ & $\begin{array}{l}\text { Baik } \\
(\mathrm{Km})\end{array}$ & $\begin{array}{c}\text { Sedang } \\
(\mathrm{Km})\end{array}$ & $\begin{array}{c}\text { Rusak } \\
\text { Ringan } \\
(\mathrm{Km})\end{array}$ & $\begin{array}{l}\text { Rusak } \\
\text { Berat } \\
(\mathrm{Km})\end{array}$ \\
\hline 1 & Negara & 194 & 182.0 & 12.0 & - & 99.1 & - & 94.9 & - \\
\hline 2 & Provinsi & 43 & 28.0 & 15.0 & - & 20.6 & - & 9.0 & 13.4 \\
\hline 3 & Kabupaten & 780.4 & 115.5 & 474.9 & 190 & 239.5 & 116.2 & 160.3 & 277.8 \\
\hline
\end{tabular}

Sumber : Dinas PU Kabupaten Buol

Tabel 9. Panjang Jalan KTM Ke Kota Buol dan Keadaan Jalan

\begin{tabular}{cccccccccc}
\hline No & Nama Jalan & $\begin{array}{c}\text { Total } \\
\text { Panjang } \\
(\mathrm{Km})\end{array}$ & $\begin{array}{c}\text { Aspal } \\
(\mathrm{Km})\end{array}$ & $\begin{array}{c}\text { Kerikil } \\
(\mathrm{Km})\end{array}$ & $\begin{array}{c}\text { Tanah } \\
(\mathrm{Km})\end{array}$ & $\begin{array}{c}\text { Baik } \\
(\mathrm{Km})\end{array}$ & $\begin{array}{c}\text { Sedang } \\
(\mathrm{Km})\end{array}$ & $\begin{array}{c}\text { Rusak } \\
\text { Ringan } \\
(\mathrm{Km})\end{array}$ & $\begin{array}{c}\text { Rusak } \\
\text { Berat } \\
(\mathrm{Km})\end{array}$ \\
\hline 1 & $\begin{array}{c}\text { Ke Kecamatan } \\
\text { Momunu }\end{array}$ & 22 & 18.8 & 3.2 & - & 2.7 & - & 5.8 & 13.5 \\
2 & $\begin{array}{c}\text { Ke Kecamatan } \\
\text { Tiloan }\end{array}$ & 40 & 25.3 & 14.7 & - & 5.6 & - & 15.9 & 18.5 \\
3 & $\begin{array}{c}\text { Ke Kecamatan } \\
\text { Bukal }\end{array}$ & 32 & 9.9 & 22.1 & - & 9.3 & 2.4 & 3.2 & 17.1 \\
\hline
\end{tabular}




\begin{tabular}{lccccccccc}
\hline & $\begin{array}{c}\text { Ke Kecamatan } \\
\text { Bokat }\end{array}$ & 37 & 21.5 & 15.5 & - & 22.7 & 2.3 & 2.1 & 10.0 \\
\hline Sumber: & Hasil Survey Lapangan
\end{tabular}

Sumber : Hasil Survey Lapangan

Pada tabel 8 menunjukkan bahwa presentase kondisi jalan untuk tiap-tiap kecamatan $75.6 \%$ merupakan jalan aspal, $42.4 \%$ jalan kerikil yang mana kondisi jalan tersebut $30.8 \%$ kondisi baik, 3.6\% sedang, $20.6 \%$ rusak ringan dan $45.0 \%$ rusak berat hal ini myatakan bahwa keseluruhan jaringa jalan yang menuju kawasan KTM air terang mengalami kerusakan. Untuk presentase kerusakan dari masing-masing kecamatan yaitu kecamatan Momunu kondisi jalan rusak ringan dan berat sebesar 87.7\%, kecamatan Tiloan 86\%, kecamatan Bukal 63.4\%, kecamatan Bokat 32.7\%.

b) Prasarana terminal.

Terdapat dua buahterminal yang ada di Kabupaten Buolnamun sampai saat ini fungsinya masih berupa pangkalan angkutan umum saja karna belum berfungsinya secara maksimal fasilitas umum dan kemampuan aparat dalam mengelola terminal yang ada belum memadai. Kedua terminal tersebut berada diluar kota Buol yaitu terletak di perbatasan Kelurahan Buol dan perbatasan Kelurahan Leok I yang mana kedua kelurahan tersebut merupakan pintu masuk ke Kota Buol. Untuk terminal yang terletak di Kelurahan Buol melayani rute angkutan kota (AK) dan angkutan pedesaan (ADES) sedangkan untuk terminal yang terletak di Kelurahan Leok I selain melayani rute angkutan kota dan perdesaan juga melayani angkutan antar kota dalam provinsi (AKDP).

c) Prasarana Pelabuhan

Kabupaten Buol mempunyaitiga buah pelabuhan laut yaitu pelabuhan Lokodidi, pelabuhan Kumaligon dan pelabuhan Leok dimana ketiga pelaabuhan ini diharapkan mampu melayani pergerakan orang maupun barang namun salah satu pelabuhan yaitu pelabuhan lokodidi yang terletak sekitar $50 \mathrm{Km}$ dari kota Buol tidak lagi berfungsi dengan baik. Untuk pelabuhan Kumaligon melayani pergerakan barang yang diangkut dengan menggunakan kapal kayu serta merupakan pelabuhan khusus melayani pengangkutan CPO oleh perusahaan kelapa sawit. Dan untuk pelabuhan Leok merupakan pelabuhan utama yang melayani angkutan orang dan barang.

\section{Sarana Transportasi}

Sarana transportasi di Kabupaten Buol terdiri darat dan laut. Khusus untuk perkembangan penggunaan sarana transportasi darat di Kabupaten Buol secara umum terus meningkat baik dalam jumlah maupun variasi kendaraan sebab sarana angkutan darat memegang peranan penting karena disamping dipergunakan sebagai angkutan penumpang juga dipakai sebagai angkutan barang/hasil komoditas pertanian dan perkebunan. Mengingat keadaan geografis di kawasan Kota Terpadu Mandiri pada empat kecamatan yang kesemuannya berupa dataran tinggi dan perbukitan, sehingga sangat membutuhkan sarana angkutan yang memadai dalam rangka memudahkan mobilitas penduduk, distribusi orang dan barang.

\section{Analisis Hirarki Simpul Pergerakan}

Untuk mendapatkan posisi hirarki simpul pada kawasan KTM Air Terang, maka digunakan analisis skalogram, metode ini digunakan untuk menjawab fasilitas 
pelayanan sosial ekonomi yang terdapat pada suatu wilayah serta simpul-simpul pengumpul, pengumpan dan distribusi.

Tabel 10. Tabel Skalogram Ketersedian fasilitas

\begin{tabular}{|c|c|c|c|c|c|c|c|c|c|c|c|c|c|c|c|c|c|c|c|c|c|c|c|}
\hline \multirow{3}{*}{ Simpul } & \multicolumn{22}{|c|}{ Fasilitas Pelayanan } & \multirow{2}{*}{$\mathrm{C}$} \\
\hline & \multicolumn{9}{|c|}{ Pelayanan ekonomi } & \multicolumn{8}{|c|}{ Pelayanan Sosial } & \multicolumn{5}{|c|}{ Prasarana } & \\
\hline & 1 & 2 & 3 & 4 & 5 & 6 & 7 & 8 & 9 & 1 & 2 & 3 & 4 & 5 & 6 & 7 & 8 & 1 & 2 & 3 & 4 & 5 & \\
\hline A & 1 & 1 & 0 & 1 & 1 & 0 & 1 & 1 & 1 & 1 & 1 & 1 & 0 & 1 & 0 & 0 & 0 & 1 & 1 & 1 & 0 & 1 & 68.18 \\
\hline B & 1 & 1 & 0 & 1 & 1 & 1 & 1 & 1 & 1 & 1 & 1 & 1 & 0 & 1 & 1 & 1 & 0 & 1 & 1 & 1 & 1 & 1 & 90.90 \\
\hline $\mathrm{C}$ & 1 & 1 & 0 & 0 & 1 & 0 & 1 & 1 & 1 & 1 & 0 & 1 & 0 & 0 & 0 & 1 & 1 & 1 & 1 & 1 & 0 & 1 & 63.63 \\
\hline D & 1 & 0 & 0 & 0 & 1 & 0 & 1 & 0 & 1 & 1 & 1 & 0 & 0 & 0 & 0 & 0 & 0 & 1 & 1 & 1 & 0 & 1 & 45.45 \\
\hline
\end{tabular}

Sumber : Hasil Analisis


Gambar 1. Peta Hirarki Simpul Pergerakan wilayah KTM Air Terang.

Aksesibilitas

Penentuan indeks aksesibilitas suatu wilayah berdasarkan Standar Pelayanan Minimum (SPM) yang dikeluarkan melalui keputusan menteri Kimpraswil No. 534/KPTSM/2001. Adapun nilai indeks aksesibilitas tiap kecamatan diwilayah KTM dapat dilihat pada tabel berikut :

Tabel 11. Indeks Aksesibilitas tiap kecamatan

\begin{tabular}{|c|c|c|c|c|c|}
\hline No & Kecamatan & $\begin{array}{c}\text { Total } \\
\text { panjang } \\
(\mathrm{km})\end{array}$ & $\begin{array}{l}\text { Luas } \\
\text { wilayah } \\
\left(\mathrm{km}^{2}\right)\end{array}$ & $\begin{array}{c}\text { Ketersediaan } \\
\text { prasarana } \\
\text { jalan } \\
\left(\mathrm{km} / \mathrm{km}^{2}\right)\end{array}$ & Keterangan \\
\hline 1 & Momunu & 82,90 & 400,40 & 0,20 & $1 \mathrm{~km}$ jalan melayani $4,82 \mathrm{~km}^{2}$ wilayah \\
\hline 2 & Tiloan & 100,80 & $1.437,70$ & 0,07 & $1 \mathrm{~km}$ jalan melayani $14,2 \mathrm{~km}^{2}$ wilayah \\
\hline 3 & Bukal & 95,37 & 355,52 & 0,26 & $1 \mathrm{~km}$ jalan melayani $3,72 \mathrm{~km}^{2}$ wilayah \\
\hline 4 & Bokat & 90,20 & 196,10 & 0,45 & $1 \mathrm{~km}$ jalan melayani $2,17 \mathrm{~km}^{2}$ wilayah \\
\hline
\end{tabular}

Sumber : Hasil Analisis

Mobilitas

Mobilitas merupakan faktor yang penting dalam menunjang pergerakan masyarakat dalam memenuhi kebutuhan. Faktor ini bermanfaat untuk melihat kecukupan antara total jaringan jalan dengan jumlah penduduk yang dinyatakan dalam Km/1000 Orang. Adapun nilai indeks mobilitas dapat dilihat dari tabel berikut:

Tabel 12. Indeks Mobilitas tiap kecamatan

\begin{tabular}{ccccc}
\hline No & Kecamatan & $\begin{array}{c}\text { Total } \\
\text { panjang } \\
(\mathrm{km})\end{array}$ & $\begin{array}{c}\text { Jumlah } \\
\text { penduduk } \\
\text { (jiwa) }\end{array}$ & $\begin{array}{c}\text { Pelayanan } \\
\text { prasarana } \\
\text { jalan }\end{array}$ \\
\hline
\end{tabular}




\section{$(\mathrm{km} / 1000)$}

\begin{tabular}{lccccc}
\hline 1 & Momunu & 82,90 & 13.237 & 6,26 & $1 \mathrm{~km}$ jalan melayani 159 orang \\
2 & Tiloan & 100,80 & 7.693 & 13,10 & $1 \mathrm{~km}$ jalan melayani 76 orang \\
3 & Bukal & 95,37 & 12.264 & 7,77 & $1 \mathrm{~km}$ jalan melayani 128 orang \\
4 & Bokat & 90,20 & 12.219 & 7,38 & $1 \mathrm{~km}$ jalan melayani 135 orang \\
\hline
\end{tabular}

Sumber: Hasil analisis

Dari diatas menunjukkan bahwa aspek aksesibilitas di wilayah KTM Air Terang masih dalam kategori baik dengan indeks aksesibilitas yang mencapai $+0,40$ dengan kepadatan penduduk $62,31 \mathrm{Jiwa} / \mathrm{Km}^{2}$. Untuk aspek mobilitas penduduk dengan $1 \mathrm{Km}$ panjang jalan dapat melayani 159 Jiwa penduduk atau 0,159 Km/1000 Jiwa penduduk.

Kinerja Jaringan Jalan

Terhadap kinerja jaringan jalan yang ada pada masing-masing kecamatan dalam kawasan Kota Terpadu Mandiri digunakan indikator kerusakan jalan yakni panjang jalan dalam kondisi baik (mantap) terhadap total panjang jalan yang dinyatakan dengan persentase.

Tabel 13. Kondisi jaringan jalan kabupaten (\%)

\begin{tabular}{clcccc}
\hline No & Kecamatan & $\begin{array}{c}\text { Total } \\
\text { Panjang } \\
(\mathrm{km})\end{array}$ & $\begin{array}{c}\text { Kondisi Jalan } \\
\text { Baik } \\
(\mathrm{km})\end{array}$ & $\begin{array}{c}\% \\
\text { Perbandingan }\end{array}$ & Kategori \\
\hline 1 & Momunu & 82,90 & 44,55 & 53,73 & Kurang Baik \\
2 & Tiloan & 100,80 & 70,70 & 70,13 & Baik \\
3 & Bukal & 95,37 & 42,10 & 44,14 & Tidak Baik \\
4 & Bokat & 90,20 & 44,60 & 49,44 & Tidak Baik \\
\hline
\end{tabular}

Sumber: Hasil analisis

Jaringan Pelayanan

Jaringan pelayanan dalam penelitian ini adalah jaringan pelayanan untuk menunjang distribusi dan pamasaran hasil produksi yang lebih efektif dan efisien, pembangunan / pemeliharaan prasarana jalan akan sangat menentukan kelancaran pergerakan dan pemasaran hasil produksi dimaksud. Tanpa prasarana jalan yang memadai, komoditas hasil produksi masyarakat suatu daerah tidak dapat memiliki nilai ekonomi yang tinggi alasannya, kondisi jalan yang tidak memadai akan berdampak pada biaya angkutan orang dan barang yang tinggi ke pusat distribusi.

Konsep strategi yang harus dilakukan adalah dengan memanfaatkan jaringan jalan yang telah ada yang menghubungkan antara desa dengan kecamatan, kecamatan satu dengan kecamatan lainnya, serta ke kota kabupaten sebagaimana hasil analisis hirarki simpul pergerakan guna pengembangan kawasan KTM Air Terang serta memudahkan masyarakat dalam memasarkan produksinya keluar kawasan hingga pemasaran keprovinsi dan kabupaten lain. Adapun ruas jalan yang harus dipriotitaskan pengembangannya adalah sebagimana dalam tabel-tabel berikut :

Tabel 14. Ruas Jalan Arteri pada kawasan KTM Air Terang.

\begin{tabular}{cccccc}
\hline \multirow{2}{*}{ Nama Ruas } & Total Panjang & \multicolumn{4}{c}{ Kondisi Jalan } \\
\cline { 3 - 5 } & $(\mathrm{Km})$ & Baik & Sedang & $\begin{array}{c}\text { Rusak Ringan } \\
(\mathrm{Km})\end{array}$ & $\begin{array}{c}\text { Rusak Berat } \\
(\mathrm{Km})\end{array}$ \\
\hline
\end{tabular}




\begin{tabular}{cccccc}
\hline & & $(\mathrm{Km})$ & $(\mathrm{Km})$ & & \\
\hline Buol - Momunu & 22 & 2.7 & - & 5.8 & 13.5 \\
Momunu-Tiloan & 18 & 2.9 & - & 10.1 & 5.0 \\
Buol - Bukal & 32 & 9.3 & 2.4 & 3.2 & 17.1 \\
Buol - Bokat & 37 & 22.7 & 2.3 & 2.1 & 10.0 \\
\hline J u m l a h & 109 & 37.6 & 4.7 & 21.2 & 45.6 \\
\hline
\end{tabular}

Sumber : Dinas PU Kabupaten Buol

Tabel 15. Ruas Jalan Kolektor pada kawasan KTM Air Terang

\begin{tabular}{lcccccc} 
& & \multicolumn{5}{c}{ Kondisi Jalan } \\
\cline { 3 - 7 } \multicolumn{1}{c}{ Nama Ruas } & $\begin{array}{c}\text { Total } \\
\text { Panjang } \\
(\mathrm{Km})\end{array}$ & $\begin{array}{c}\text { Baik } \\
(\mathrm{Km})\end{array}$ & $\begin{array}{c}\text { Sedang } \\
(\mathrm{Km})\end{array}$ & $\begin{array}{c}\text { Rusak } \\
\text { Ringan } \\
(\mathrm{Km})\end{array}$ & $\begin{array}{c}\text { Rusak } \\
\text { Berat } \\
(\mathrm{Km})\end{array}$ & $\begin{array}{c}\text { Belum } \\
\text { Tembus } \\
(\mathrm{Km})\end{array}$ \\
\hline Potangoan - Modo I & 6.1 & - & 4,1 & - & 2,0 & - \\
Sp. Air Terang - Modo IV & 38,0 & 20,0 & 4,3 & - & 13,7 & - \\
Negeri Lama - Bungkudu & 4,1 & 1,0 & - & - & 3,1 & - \\
Bungkudu - Mopu & 9,0 & 1,0 & 0,5 & 1,1 & 6,4 & - \\
Kantanan - Unone & 8,8 & 2,2 & - & 1,3 & 5,3 & - \\
Lamadong - Biau & 6,6 & 0,8 & 2,1 & 1,4 & 2,3 & - \\
Sp. Bongo - Despot & 5,8 & 4,2 & - & 1,6 & - & - \\
Kumaligon - Air Terang & 39,0 & 17,0 & 1,5 & 1,5 & 19,0 & - \\
Despot - Modo I & 13,7 & 2,5 & 2,0 & 1,0 & 8,2 & - \\
Tayadun - Poongan & 8,0 & - & 2,0 & 2,0 & 4,0 & - \\
Air Terang - Kokobuka & 15,0 & 3,4 & - & 5,3 & 6,3 & - \\
Rantemaranu - winangun & 13,0 & 10,5 & - & 2,5 & - & - \\
Kokobuka - Moutong & 60,0 & - & - & 5,0 & 25,0 & 30,0 \\
Air Terang - Lampasio & 100,0 & - & - & 10,0 & 35,0 & 55,0 \\
\hline J u m I a h & $\mathbf{3 2 7 , 1}$ & $\mathbf{6 2 , 6}$ & $\mathbf{1 6 , 5}$ & $\mathbf{3 2 , 7}$ & $\mathbf{1 3 0 , 3}$ & $\mathbf{8 5 , 0}$ \\
\hline Sumyyyyyyyy
\end{tabular}

Sumber : Dinas PU Kabupaten Buol.

Oleh karena melihat tingkat kerusakan jalan yang demikian besar makadiperlukan perhatian pemerintah dalam penanganan jaringan jalan diKota Terpadu Mandiri Air Terang yang diharapkan untuk mencapai tujuan sebagai berikut :

a) Meningkatkan kelancaran distribusiproduk pertanian dari wilayah KTM air Terangyang lebih efektif dan efisien.

b) Pembangunan dan peningkatan jaringan jalan guna mendukung sistem transportasi wilayah Kota Terpadu Mandiri Air Terang.

c) Meningkatkan mobilitas orang maupun barang yang dapat menunjang pertumbuhan ekonomi dan memenuhi kebutuhan sosial masyarakat.

d) Terbukanya jalan ke kawasan sentra-sentra produksi lainya sehingga mempercepat pertumbuhan dan pengembangan wilayah Kota Terpadu Mandiri Air Terang serta kecamatan lain disekitarnya.

Analisis Strategi Pengembangan Jaringan Jalan

Pengembangan jaringan jalan di kawasan KTM Air Terang merupakan bagian integral dari pembangunan nasional dan pembangunan di Kabupaten Buol, yang pelaksanaannya disesuaikan dengan kondisi dan potensi wilayah pada empat kecamatan. Strategi yang dipergunakan dalam pengembangan jaringan jalan dilakukan dengan menggunakan pendekatan analisis SWOT (Strength, Weakness, Opportunity, and Threat). Analisis SWOT ini bertujuan untuk mengidentifikasi 
faktor-faktor internal dan eksternal.Faktor internal meliputi kekuatan dan kelemahan sedangkan faktor eksternal meliputi peluang dan ancaman.

Tahap pengambilan data ini digunakan untuk mengetahui faktor-faktor yang menjadi kekuatan, kelemahan, peluang dan ancaman yang dilakukan dengan wawancara terhadap ahlinya atau analisis kuantitatif. Berdasarkan hasil analisis SWOT, dapat dilakukan strategi pengembangan jaringan jalan dalam menunjang pertumbuhan dan pengembangan wilayah di kawasan KTM Air Terang sebagai berikut :

a) Pembangunan/pemeliharaan jaringan jalan menuju kawasan-kawasan potensial untuk menunjang pertumbuhan dan pengembangan wilayah

Berdasarkan hasil identifikasi potensi ekonomi di kawasan KTM Air Terang yang merupakan basis pertanian dan perkebunan, sampai saat ini jaringan jalan yang menghubungkan ke empat wilayah tersebut masih sangat terbatas khususnya kecamatan Tiloan menuju kecamatan Bukal dan kecamatan Bokat dikarenakan pada kedua wilayah tersebut terdapat wilayah perkebunan sawit yang dikelola oleh PT. Hardaya Inti Plantation. Untuk itu perlu dilakukan kerjasama antara pemerintah daerah dengan pihak perusahaan untuk menyepakati penggunaan jaringan jalan kawasan perkebunan sebagai salah satu jalan penghubung kedua kecamatan tersebut.

Pembanagunan/Pemeliharaan jaringan jalan yang telah dilaksanakan oleh pemerintah harus lebih fokus pada jaringan jalan yang menunjang distribusi pergerakan orang dan barang diwilayah KTM Air Terang sebagaimana daftar jaringan jalan kolektor berdasarkan penetapan hirarki kecamatan dan jaringan jalan tersebut merupakan jalan utama yang dapat menghubungkan keempat kecamatan diwilayah KTM Air Terang. Pembangunan/pemeliharaan jaringan jalan ini selain sebagai jalan utama penghubung antar kecamatan juga merupakan jaringan jalan yang berbatasan langsung dengan lahan-lahan potensial masyarahat sehingga petani dalam mengangkut hasil produksinya dari areal pertanian dan perkebunan ketempat penampungan sementara sebelum dipasarkan menjadi lebih mudah.

Kondisi jalan yang sebahagian besar mengalami kerusakan merupakan kendala terbesar dalam distribusi pergerakan orang dan barang diwilayah KTM Air Terang dimana tingkat kerusakan jalan mencapai $61,19 \%$ hal ini dibutuhkan keseriusan pemerintah dalam menangani permasalahan tersebut terlebih khusus dalam masalah penetapan anggaran pembangunan/pemeliharaan jalan dalam belanja APBD kabupaten sehingga pengalokasian dana pembangunan /pemeliharaan ruas jalan harus lebih mengacu pada distribusi hasil produksi dari lokasi-lokasi produksi di wilayah KTM Air Terang ke tempat pemasaran di kota Buol. Disamping itu perlu pula dikembangkan jalan usaha tani atau jalan kantong produksi yang selama ini masih belum tertangani khusus pada wilayah KTM Air terang dimana pada saat ini wilayah tersebut juga telah menerima kembali para Transmigran yang sejak tahun 2008 sampai dengan tahun 2011 jumlahnya mencapai $1500 \mathrm{kk}$ yang tersebar di Kecamatan Tiloan dan Kecamatan Bokat, kondisi ini sangat membutuhkan infrastruktur dan sarana prasarana yang memadai. Demikian pula areal olahan yang diperuntukkan bagi masyarakat transmigran tersebut dibuka areal seluas $\pm 7.000 \mathrm{Ha}$, dimana hal ini harus didukung dengan jaringan jalan usaha tani yang memadai guna memudahkan masyarakat dalam melakukan aktifitasnya dilokasi lahan olahan miliknya.

b) Peningkatan sarana transportasi dalam mendukung mobilitas penduduk 
Perkembangan transportasi yang pesat pada saat ini telah mempengaruhi berbagai aspek kehidupan. Seiring dengan meningkatnya kapasitas kendaraan dari tahun ke tahun maka perlu diadakan peningkatan terhadap prasarana jalan. Faktor perekonomian merupakan salah satu faktor yang berpengaruh yang menyebabkan perkembangan kuantitas kendaraan, baik kendaraan umum maupun kendaraan pribadi. Berdasarkan pengamatan mobilitas penduduk pada wilayah KTM khususnya untuk wilayah kecamatan Momunu dan Kecamatan Tiloan sangat tinggi dibandingkan dengan kecamatan lain hal ini disebabkan produktifitas masyarakat pada wilayah ini sangat tinggi untuk mengimbangi hal tersebut diperlukan peningkatan sarana transportasi yang memadai, dimana saat ini moda angkutan orang maupun barang yang beroperasi diwilayah KTM Air Terang sangat terbatas jumlah dan jenisnya, hal ini disebabkan kondisi jalan pada wilayah ini yang sebahagian besar mengalami kerusakan sehingga biaya transportasi yang dibutuhkan dalam melakukan perjalanan menjadi mahal serta waktu tempuh yang dibutuhkan menjadi lama.

Sarana transportasi yang melayani rute antar kecamatan diwilayah KTM Air Terang belum tersedia, dimana kendaraan yang melayani rute antar kecamatan tersebut hanya menggunakan jasa angkutan kendaraan roda dua selain dikarenakan kondisi jalan juga karena belum adanya pengusaha yang mau berinvestasi dengan kendaraan roda empat dalam melayani rute ini. Olehnya itu melihat rencana percepatan pembangunan wilayah KTM Air Terang, maka dibutuhkan pula perhatian pemerintah untuk mengatasi masalah prasarana transportasi tersebut dengan penyediaan sarana transportasi pedesaan atau angkutan perintis yang dapat melayani mobilitas masyarakat antar kecamatan serta antar desa utamanya pada desa-desa penempatan transmigrasi baru.

Oleh karena itu pembangunan/pemeliharaan jaringan jalan dan penyediaan sarana transportasi di kawasan KTM Air Terang diarahkan untuk mencapai tujuan sebagai berikut : 1) meningkatkan kelancaran arus lalu lintas angkutan orang dan barang; 2) terbangunnya suatu jaringan jalan dan sistem transportasi yang lebih efektif dan efisien; 3) meningkatkan mobilitas orang maupun barang yang dapat menunjang pertumbuhan ekonomi dan memenuhi kebutuhan sosial masyarakat; 4) peningkatan prasarana transportasidalam mendukung mobilitas pendudukanatar wilayah pedesaan; 5) terbukanya jalan ke wilayah terisolir dan terpencil dan kawasan sentra-sentra produksi; 6) pempercepat pencapaian fungsi Kota Terpadu Mandiri sebagai pusat pengembangan kegiatan agrobisnis dan agroindustri serta pusat perdagangan wilayah.

\section{KESIMPULAN}

Dari hasil analisis dan pembahasan maka dapat ditarik kesimpulan sebagai berikut:

1) Berdasarkan hasil analisis deskriptif kualitatif dan kuantitatif dengan melihat potensi sumber daya alam yang ada diwilayah KTM Air Terang menunjukkan bahwa produksi yang sangat besar dimana untuk produksi pertanian per tahun dengan luas panen 4.472 ha dengan jumlah produksi 22.806 ton demikian pula dengan jumlah produksi untuk jenis tanaman pangan lainya yang cukup besar. Untuk produksi perkebunan jenis tanaman yang menonjol ialah Kakao dan kelapa dalam yakni sebanyak 46,10\% dari volume produksi diwilayah KTM Air Terang diikuti oleh tanaman cengkeh, kopi robusta dan nilam. Komoditas ini dikembangkan cukup aktif di semua kecamatan diwilayah KTM Air Terang serta 
potensi lain yang dikembangkan diantaranya potensi peternakan, potensi kehutanan dan lainnya, merupakan bangkitan pergerakan transportasi diwilayah KTM Air Terang yang membutuhkan sarana dan prasarana transportasi dalam mendukung distribusi orang dan barang dari tempat asal ke tujuan untuk proses produksi.

2) Dengan memperhatikan analisis aksesibilitas dan mobilitas jaringan jalan yang ada diwilayah KTM Air Terang memperlihatkan bahwa ketersediaan prasarana jalan sudah mencukupi berdasarkan kepadatan penduduk dengan indeks aksesibilitas mencapai $+0,40$ dan kepadatan penduduk $62,31 \mathrm{Jiwa} / \mathrm{Km}^{2}$ serta aspek mobilitas dengan $1 \mathrm{Km}$ panjang jalan dapat melayani 159 jiwa penduduk atau $0,159 \mathrm{Km} / 1000$ jiwa penduduk.

3) Jaringan jalan arteri yang melayani pergerakan penduduk diwilayah KTM Air Terang sepanjang $109 \mathrm{Km}$ dengan kondisi baik 38,81\% dan kondisi rusak berat mencapai $61,19 \%$ membutuhkan penanganan dari pihak pemerintah baik berupa peningkatan maupun pemeliharaan jalan agar mobilitas penduduk KTM dari dan kekota Buol dapat lebih efektif dan efisien sehingga menunjang pertumbuhan ekonomi masyarakat.

4) Dalam melayani pergerakan penduduk antar desa, kecamatan serta kekantong produksi atau jalan usaha tani diwilyah KTM Air Terang maka diperlukan pula penanganan jalan kolektor yang menghubungkan wilayah-wilayah tersebut. Kondisi jalan kolektor yang mengalami kerusakan mencapai 75,82\% kondisi ini menyebabkan aktifitas penduduk antar kecamatan menjadi rendah.

5) Dari analisis SWOT didapatkan strategi ST: Pembangunan/pemeliharaan jaringan jalan menuju kawasan-kawasan potensial untuk menunjang pertumbuhan dan pengembangan wilayah KTM Air Terang dengan melihat potensi sumber daya alam yang tersedia pada masing-masing kecamatan sehingga pembangunan/ pemeliharaan jaringan jalan ini dapat membantu memudahkan masyarakat mengangkut hasil pertanian dan perkebunannya dari lokasi lahan pertanian yang untuk selanjutnya dipasarkan. Hal ini harus didukung pula dengan ketersediaan sarana transportasi yang memadai sehingga distribusi hasil produksi kelokasi pemasaran menjadi lebih efektif dan efisien.

\section{DAFTAR PUSTAKA}

Adisasmita, R., 2008. Traansportasi dan Pengembangan Wilayah. Graha Ilmu, Yogyakarta.

Badan Pusat Statistik Kabupaten Buol, 2010.Buol Dalam Angka.

Departemen Kimpraswil, 2004. Pengembangan Indikator Efektifitas Pelaksanaan Program Prasarana Wilayah, Jakarta.

Jinca, M. Y., 2007. Dasar-Dasar Transportasi. Bahan Kuliah Fakultas Teknik Universitas Hasanuddin, Makassar.

Jinca, M. Y. dkk., 2002. Perencanaan Transportasi.kerjasama Fakultas Teknik Unhas Makassar, dengan Pusat Penddikan Keahlian Teknik BPSDM Departemen Prasarana Wilayah, Bandung.

Jinca, M. Y., 1999. Sistem dan Teknik Transportasi. Bahan Kuliah Fakultas Teknik Universitas Hasanuddin, Makassar.

Keputusan Permukiman dan Prasarana Wilayah Nomor 534/KPTS/M/2001, Tentang Standar Pelayanan Minimal (SPM), Jakarta 
Miro, F., 2005. Perencanaan Transportasi. Erlangga, Jakarta.

Munawar, A., 2005. Dasar-Dasar Teknik Transportasi. Beta Offset, Yogyakarta.

Morlok, E. K., 1995. Pengantar Teknik Perencanaan Transportasi. Terjemahan oleh Hainim,J.K.,Erlangga,Jakarta. 